\title{
Nausea and vomiting in palliative care
}

\author{
Author: Charlotte Leach ${ }^{\mathrm{A}}$
}

Nausea and vomiting in palliative care are commonly experienced symptoms, and the aetiology is often multifactorial. The most common causes are impaired gastric emptying, chemical causes (eg medication) and visceral causes (eg constipation). Close attention should be paid to the clinical features which may suggest the likely cause. Antiemetic therapy should be guided by the likely aetiology, although in practice, the clinical picture is often complex, and so regular reassessment is essential for adequate symptom control.

\section{Introduction}

Nausea and vomiting $(\mathrm{N} \& \mathrm{~V})$ are commonly experienced by patients receiving palliative care, and may result from the primary disease itself, treatment for the disease (medication, anti-cancer therapies) or co-existing diseases (and their treatments). Given that one-third of hospital inpatients are in the last year of life, physicians should have a sound working knowledge of assessment and management of common symptoms for patients receiving palliative care. This article will focus on the assessment and pharmacological management of nausea and vomiting (excluding chemotherapy-induced $\mathrm{N} \& \mathrm{~V}$ ).

\section{Epidemiology}

$\mathrm{N} \& \mathrm{~V}$ are common, but distinct, symptoms experienced by patients receiving palliative care. Nausea is 'the unpleasant feeling of the need to vomit', whereas vomiting is 'the forceful expulsion of gastric contents through the mouth'. 2 Patients may also complain of retching, which is 'the attempt to vomit without bringing anything up. ${ }^{3}$ Although they are separate entities, N\&V often occur together. Stephenson et al report that $62 \%$ of patients with advanced cancer report N\&V. ${ }^{4}$ As isolated entities, the prevalence of nausea ranges from $6-68 \%$ in patients with advanced cancer, ${ }^{5}$ and the prevalence of vomiting is $4 \%$ in patients with advanced cancer. ${ }^{4}$

\section{Aetiology}

In clinical practice, $N \& V$ are often multi-factorial symptoms. According to Stephenson et al, the causes in their study were impaired gastric emptying (44\%); chemical causes (33\%); visceral/serosal pathology (31\%); cranial causes (8\%) and cortical reasons (7\%). ${ }^{4}$

Author: ${ }^{\text {A }}$ consultant in palliative medicine, Royal Surrey County Hospital, Guildford, UK

\begin{tabular}{|c|c|}
\hline Category & Sub-groups \\
\hline \multirow[t]{3}{*}{ Chemical } & Drugs eg opioids, antibiotics \\
\hline & Toxins eg gut ischaemia, infection \\
\hline & Metabolic eg hypercalcaemia, renal failure \\
\hline \multirow{2}{*}{$\begin{array}{l}\text { Impaired gastric } \\
\text { emptying }\end{array}$} & Drugs eg opioids, tricyclics \\
\hline & Autonomic dysfunction \\
\hline Visceral/serosal & $\begin{array}{l}\text { eg obstruction of hollow viscus, stretched liver } \\
\text { capsule }\end{array}$ \\
\hline Cranial & $\begin{array}{l}\text { Raised intracranial pressure eg tumour, } \\
\text { infarction }\end{array}$ \\
\hline \multirow[t]{2}{*}{ Vestibular } & Drugs eg opioids \\
\hline & Base of skull tumour \\
\hline Cortical & Anxiety, pain \\
\hline
\end{tabular}

Table 1 outlines common causes and examples of N\&V. It should be noted that many patients in this study had more than a single cause for their $\mathrm{N} \& \mathrm{~V}$.

\section{Key points}

Nausea and vomiting are common, distressing symptoms in patients receiving palliative care.

Nausea and vomiting may be due to the primary disease, treatment sequelae (medication, anti-cancer therapies) and co-existing disease.

Assessment should identify the likely aetiology.

Nausea and vomiting are often multifactorial.

Common pitfalls include poor assessment, using inappropriate antiemetics and using multiple antiemetics with the same mechanism of action.

KEYWORDS: Nausea, vomiting, palliative care, antiemetic 
Fig 1. Key emetogenic pathways. ${ }^{4,8}$ Ach $=$ Acetylcholine receptor; $\mathrm{CTZ}=$ chemoreceptor trigger zone; $\mathrm{D} 2$ = dopamine type 2 receptor; $\mathrm{GABA}=$ gammaaminobutyric acid receptor: $\mathrm{H} 1$ = histamine type 1 receptor; ICP $=$ intracranial pressure; NK1 = neurokinin 1 receptor; $5 \mathrm{HT} 2=$ serotonin type 2 receptor; $5 \mathrm{HT} 3=$ serotonin type 3 receptor; 5 HT4 = serotonin type 4 receptor.

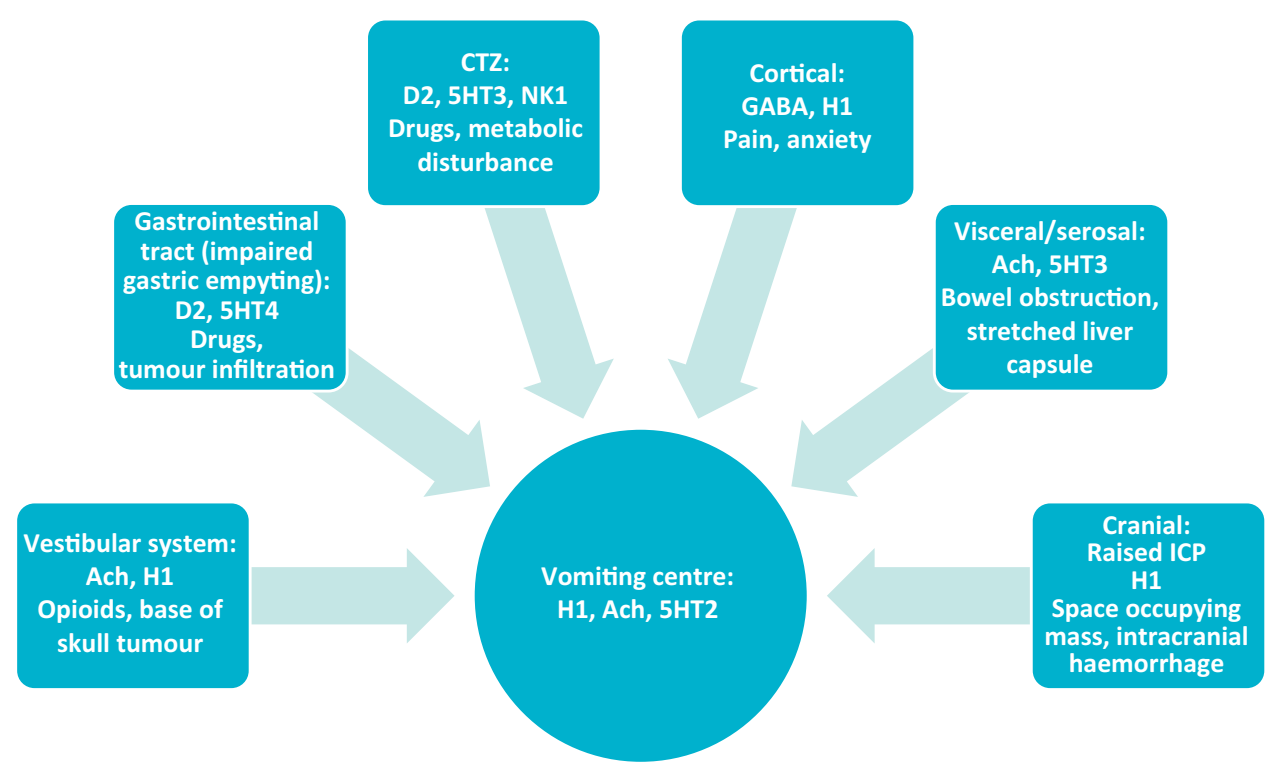

\section{Clinical features}

The clinical features of N\&V may suggest an underlying aetiology. Gastric stasis may present with a feeling of early satiety, bloating and $N \& V$ soon after eating. Opioid-induced $N \& V$ usually occurs after initiation of opioids, and is generally transient in nature ( $<1$ week). ${ }^{6}$ The presentation of N\&V due to malignant bowel obstruction depends on the level of the obstruction: in small bowel obstruction, nausea followed by large volume vomits is an early clinical feature, and is often associated with central, colicky abdominal pain; vomiting is often a later feature in large bowel obstruction. ${ }^{7}$ N\&V due to biochemical causes are usually constant symptoms, and coincide with initiation of a drug, or development of the relevant problem.

$N \& V$ can cause significant distress and impair a patient's quality of life. Rhodes et al suggest that the associated distress escalates over the duration of the symptom, ${ }^{3}$ reinforcing the need for early assessment and intervention. Furthermore, N\&V can result in significant physical complications including dehydration, electrolyte derangement and malnutrition. ${ }^{8}$

\section{Assessment}

A focussed history and examination is essential, supported by appropriate investigations (eg biochemistry, radiology). The objectives of assessment should be to identify the likely cause of $N \& V$, establish the response to previous antiemetic therapy and identify any complications of N\&V (eg dehydration, electrolyte disturbance). Re-assessment is as important as assessment, with the main purpose being to review the efficacy and tolerability of the initial antiemetic medication.

\section{Treatment}

Explanation of the likely cause and proposed treatment should be provided to the patient and their carers; they should also be counselled on potential adverse effects of prescribed antiemetics. Dependent on individual patient circumstances, it is suggested that potentially reversible causes are treated, for example, constipation should be treated with laxatives, and these will be much more effective than antiemetics in the medium term. In all cases, the appropriateness of parenteral hydration should be considered, as well as the need for electrolyte replacement (eg potassium supplements, magnesium supplements).

Broadly speaking, there are two different approaches to managing N\&V: the mechanistic approach and the empirical approach. The mechanistic approach is generally used in clinical practice, ${ }^{9}$ the underlying principle is to block the relevant emetogenic pathway by selecting an antiemetic which targets the pertinent receptor(s). Key emetogenic pathways are summarised in Fig 1. An empirical approach involves using drugs on the basis of their generic efficacy and tolerability, rather than on the basis of their specific receptor activity.

There are two main brainstem centres which receive and integrate neurotransmitters responsible for $\mathrm{N} \& \mathrm{~V}$ : the vomiting centre (VC) and the chemoreceptor trigger zone (CTZ). The VC is not a specific anatomical structure, but is a collection of nuclei, which receives input from the cerebral cortex, the vestibular system and the GI tract, as well as integrating input from the CTZ. The CTZ is in the floor of the fourth ventricle, the CTZ sits outside of the blood-brain barrier, rendering it sensitive to toxins, drugs and biochemical derangements.

Table 2 outlines the choice of antiemetic therapy based on the likely cause of N\&V. ${ }^{4}$ Concomitant use of drugs with similar receptor profiles is not recommended. Parenteral administration is recommended in cases of vomiting, poor GI absorption or significant gastric stasis. ${ }^{8}$ For maximum effect, antiemetics should be prescribed on a regular basis, titrated according to response, and reviewed frequently for effectiveness and adverse effects. ${ }^{2}$

Of note, there remains a low quality evidence for the management of $\mathrm{N} \& \mathrm{~V}$. One prospective study demonstrated that $89 \%$ of patients with advanced cancer had vomiting controlled at 1 week (and 56\% had nausea controlled at 1 week) after following an aetiology-based approach to management. ${ }^{4}$ Thus, there remains a proportion of patients for whom their symptoms will be refractory to the suggested aetiology-based approach. In such situations, referral to specialist palliative care services is 
Table 2. Antiemetic therapy based on the mechanistic approach. ${ }^{2,4,5}$ Please consult the British National Formulary and the Palliative Care Formulary for doses. Parenteral administration is recommended if the patient is vomiting

$\begin{array}{llll}\begin{array}{l}\text { Suspected cause of nausea and } \\ \text { vomiting }\end{array} & \text { Examples } & \begin{array}{l}\text { Recommended first-line } \\ \text { antiemetic }\end{array} & \begin{array}{l}\text { Recommended second-line } \\ \text { antiemetic }\end{array} \\ \begin{array}{l}\text { Chemical } \\ \text { Impaired gastric emptying }\end{array} & \text { Drugs, biochemical disturbance } & \text { Haloperidol } & \text { Levomepromazine } \\ \text { Visceral/serosal } & \text { Gastric stasis, drugs } & \text { Metoclopramide } & \text { Levomepromazine } \\ \text { Cranial } & \text { Bowel obstruction, constipation } & \text { Cyclizine } & \text { Levomepromazine } \\ \text { Vestibular } & \text { Space occupying lesion, radiotherapy } & \text { Cyclizine } & \text { Levomepromazine } \\ \text { Cortical } & \text { Base of skull tumour } & \text { Cyclizine } & \text { Levomepromazine }\end{array}$

recommended. A recent review by Walsh et al concluded that metoclopramide is the empirical drug of choice in patients with advanced cancer. ${ }^{10}$

There are several antiemetics with specific indications: selective serotonin type 3 receptor ( $5 \mathrm{HT} 3$ ) antagonists (eg ondansetron, granisetron), neurokinin 1 receptor antagonists (eg fosaprepitant, aprepitant) and synthetic cannabinoids (eg nabilone). The latter are licenced for use in chemotherapy-induced nausea and vomiting (CINV), and post-operative N\&V for selective $5 \mathrm{HT} 3$ receptor antagonists, and both NK1 receptor antagonists and synthetic cannabinoids are only available only via specialists. The routine use of selective $5 \mathrm{HT} 3$ receptor antagonists as first-line antiemetics is not recommended in patients receiving palliative care. CINV is a complex clinical problem, and is outside the scope of this article: the joint MASCC and ESMO guideline on CINV provides a comprehensive review of this topic. ${ }^{11}$

A systematic review by Ryken et al recommended that dexamethasone 4-8 $\mathrm{mg}$ daily (increasing up to $16 \mathrm{mg}$ daily in severe symptoms) should be considered for symptomatic relief of $\mathrm{N} \& \mathrm{~V}$ due to raised intracranial pressure or cerebral oedema due to metastases. ${ }^{12}$ Corticosteroids are also used to manage CINV and malignant bowel obstruction (MBO).

In cases of MBO where surgical intervention has been excluded, treatment may be either pharmacological (antiemetics, antisecretory agents) or mechanical decompression with a wide bore nasogastric tube. A trial of parenterally administered corticosteroids may be considered alongside antiemetics and antisecretory agents, and the response should be reviewed after 5 days. ${ }^{8}$ The review by Walsh et al recommends the use of octreotide and/or an anticholinergic agent in addition to an antiemetic. ${ }^{11}$

\section{Conclusion}

$\mathrm{N} \& \mathrm{~V}$ are commonly experienced symptoms, which often cause significant distress. However, most patients respond to antiemetics, although vomiting appears to be easier to control than nausea. Nevertheless, many patients require a trial of one or more antiemetics to achieve good symptom control. Patients with unrelieved symptoms should be referred for specialist assessment.

\section{Conflicts of interest}

The author has worked on a research project on opioid-induced constipation, which received an educational grant from Kyowa Kirin. The author has also received speaker and advisory board fees from Kyowa Kirin.

\section{Acknowledgements}

The author wishes to acknowledge Dr Antonia Field-Smith for her comments on this manuscript.

\section{References}

1 Clark D, Armstrong M, Allan M et al. Imminence of death among a national cohort of hospital inpatients. Pall Med 2014;28:474-9.

2 Harris D. Nausea and vomiting in advanced cancer. Br Med Bull 2010;96:175-85.

3 Rhodes V, McDaniel R. Nausea, vomiting and retching: complex problems in palliative care. Cancer ] Clin 2001;51:232-48.

4 Stephenson J, Davies A. An assessment of aetiology-based guidelines for the management of nausea and vomiting in patients with advanced cancer. Support Care Cancer 2006;14:348-53.

5 Solano J, Gomes B, Higginson I. A comparison of symptom prevalence in far advanced cancer, AIDS, heart disease, chronic obstructive pulmonary disease and renal disease. J Pain Symp Manag 2006;31:58-69.

6 Campora E, Merlini L, Pace M, Bruzzone M. The incidence of narcotic-induced emesis. J Pain Symp Manag 1991;6:428-30.

7 Ripamonti C, Easson A, Gerdes H. Bowel obstruction. In: Cherny N, Fallon T, Kaasa S, Portenoy R, Currow D (eds). Oxford Textbook of Palliative Medicine, 5th edn. Oxford: Oxford University Press, 2015.

8 Collis E, Mather H. Nausea and vomiting in palliative care. BM] 2015;351:h6249.

9 Hardy M, Glare P, Yates P, Mannix K. Palliation of nausea and vomiting. In: Cherny N, Fallon T, Kaasa S, Portenoy R, Currow D (eds). Oxford Textbook of Palliative Medicine, 5th edn. Oxford: Oxford University Press, 2015.

10 Walsh D, Davis M, Ripamonti C et al. 2016 Updated MASCC/ESMO consensus recommendations: Management of nausea and vomiting in advanced cancer. Support Care Cancer 2017;25:333-40.

11 Roila F, Molassiotis A, Herrstedt ] et al. 2016 MASCC and ESMO guideline update for the prevention of chemotherapy- and radiotherapy-induced nausea and vomiting in advanced cancer patients. Annals of Oncology 2016;27(Suppl 5):v119-33.

12 Ryken T, McDermott M, Robinson P et al. The role of steroids in the management of brain metastases: a systematic review and evidence-based clinical practice guideline. J Neurooncol 2009;96:103-14.

Address for correspondence: Dr Charlotte Leach, Royal Surrey County Hospital, Egerton Road, Guildford, Surrey GU2 7XX, UK.

Email: charlotte.leach@doctors.org.uk 